\title{
A World Without Tribes? Tribal Rights of Self-Government and the Enforcement of State Court Orders in Indian Country
}

\author{
John Arai Mitchell $\dagger$
}

A state court can generally assert jurisdiction over a civil suit arising out of Indian Country ${ }^{1}$ where state civil jurisdiction 1 ) is not preempted by federal law and 2) does not infringe upon tribal rights of self-government. ${ }^{2}$ The Supreme Court has declared that the infringement prong of this infringement-preemption test requires an analysis of both state and tribal interests: state courts can protect a state's interest up to the point where state authority affects the "right of reservation Indians to make their own laws and be ruled by them." State courts have little difficulty ascertaining the state's interest in a given controversy, but they have shown less aptitude for determining and upholding tribal interests. Indeed, they often act as if their authority were supreme, as if they existed in a world without Indian tribes. ${ }^{4}$

The "no law" cases illustrate how courts have struggled to properly characterize tribal rights of self-government without the aid of a principled framework for defining tribal interests. ${ }^{5}$ In these cases, courts must determine whether state court jurisdic-

$\dagger$ B.A. 1991, Emory University; J.D. Candidate 1994, The University of Chicago.

1 "Indian Country" is a term of art.

"Indian Country"... means (a) all land within the limits of any Indian reservation under the jurisdiction of the United States Government, notwithstanding the issuance of any patent, and including rights-of-way running through the reservation, (b) all dependent Indian communities within the borders of the United States whether within the original or subsequently acquired territory thereof, and whether within or without the limits of a state, and (c) all Indian allotments, the Indian titles to which have not been extinguished, including rights-of-way running through the same.

18 USC $\$ 1151$ (1988).

2 White Mountain Apache Tribe v Bracker, 448 US 136, 142 (1980).

${ }^{3}$ McClanahan $v$ Arizona State Tax Commission, 411 US 164, 171-72 (1973), quoting Williams $v$ Lee, 358 US 217, 220 (1959).

+ In the context of jurisdictional controversies, a tribe is a group of Indians protected by a trust relationship with the federal government and recognized as having the powers of self-government. Felix S. Cohen, Handbook of Federal Indian Law 6-7 (US GPO, 1942) ("Handbook").

5 Frank Pommersheim, The Crucible of Sovereignty: Analyzing Issues of Tribal Jurisdiction, 31 Ariz L Rev 329, 351-55 (1989) (describing the "no law" problem and collecting cases). 
tion impermissibly infringes upon tribal rights of self-government when a tribe has not legislated on an issue or has not endorsed a remedy to execute a judgment granted under state law-when there seemingly is "no (tribal) law." One line of cases holds that the application of state law impinges upon tribal sovereignty only when the tribe has explicitly addressed the issue. ${ }^{6}$ Another line of cases compares the tribal rights of self-government to state sovereignty, holding that state civil jurisdiction can impermissibly infringe upon tribal governmental authority even where the state's assertion of jurisdiction contravenes no explicit assertions of tribal law. ${ }^{7}$ These conflicting interpretations of the tribal rights of self-government have magnified the unpredictability and general jurisdictional confusion surrounding the enforcement of state court orders against Indian defendants. ${ }^{8}$

This Comment proposes an alternative approach to the "no law" problem, an approach inspired by the Supreme Court's elaboration on the tribal rights of self-government in Montana $v$ United States. ${ }^{9}$ In Montana, the Court suggested that state court civil jurisdiction over an action involving an Indian party may improperly infringe the tribal rights of self-government where the state's exercise of authority "threatens or has some direct effect on the political integrity, the economic security, or the health or welfare of the tribe." This approach recognizes that while tribal rights of self-government have been recognized as a matter of federal policy, ${ }^{11}$ they are actually grounded in the inherent right of self-determination the tribes enjoyed as nations prior to the arrival of European colonists. ${ }^{12}$ If courts faithfully applied the Montana conception of tribal rights of self-government, the

6 See, for example, Little Horn State Bank v Stops, 170 Mont 510, 555 P2d 211, 214 (1976); First v LaRoche, 247 Mont 465, 808 P2d 467, 472 (1991); R.G. v W.M.B., 159 Wis 2d 662, 465 NW2d 221, 224 (Wis App 1990); Jacobs $v$ Jacobs, 138 Wis 2d 19, 405 NW2d 668, 672 (Wis App 1987).

7 See, for example, Joe v Marcum, 621 F2d 358, 361-62 (10th Cir 1980); United States $v$ Morris, 754 F Supp 185, 187-88 (D NM 1991); Begay v Roberts, 167 Ariz 375, 807 P2d 1111, 1117 (Ariz App 1990).

8 Although the literature employs various terms to describe the indigenous people of North America, this Comment uses the term "Indian." In the context of jurisdictional controversies, an Indian is a member of a federally recognized tribe. United States $v$ Broncheau, 597 F2d 1260, 1263 (9th Cir 1979).

9450 US 544 (1981).

10 Id at 566.

11 Rosebud Sioux Tribe v South Dakota, 900 F2d 1164, 1174 (8th Cir 1990); Jane M. Smith, Republicanism, Imperialism, and Sovereignty: A History of the Doctrine of Tribal Sovereignty, 37 Buff L Rev 527, 574-75 (1988/89).

12 See Worcester $v$ Georgia, 31 US (6 Pet) 515, 557-61 (1832). 
resolution of "no law" state/tribal jurisdictional conflicts would be clear: even where the tribal code does not provide a remedy, state court jurisdiction is invalid because it violates the "political integrity" of tribal councils and undermines the authority of the tribal courts.

This Comment begins by surveying the development of the infringement-preemption test in Supreme Court Indian law jurisprudence. Next, it outlines the lower court cases that address the particularly difficult "no law" problem. Finally, this Comment applies the understanding developed in Montana to state/tribal court jurisdictional conflicts. The Comment concludes that tribal code silence should speak as loudly as any express legislative or judicial pronouncement, especially where state court jurisdiction interferes with the development of tribal common law.

\section{THE SUPREME COURT'S JURISPRUDENCE ON TRIBAL RightS OF SELF-GOVERNMENT}

The Supreme Court's vision of tribal sovereignty has evolved with the changes in the political relationship between Indian tribes and the development of tribal political and legal institutions. The Court has held consistently, however, that tribes possess rights of self-government and have authority over Indian Country to the exclusion of state power. This Section describes the Supreme Court's efforts to give legal substance to tribal sovereignty.

\section{A. Tribal Rights of Self-Government Trump State Authority}

The Supreme Court first addressed whether a state could enforce its laws within Indian Country in Worcester $v$ Georgia. ${ }^{13}$ In an opinion by Chief Justice Marshall, the Court held that Georgia could not assert jurisdiction over Cherokee territory because the federal statutes and treaties regulating trade with the Indian nations recognized each Indian nation as an indepen-

1331 US 515. Georgia officials arrested Samuel A. Worcester, a missionary from Vermont, for entering and residing within the boundaries of the Cherokee nation without express permission from the State of Georgia. Worcester challenged the validity and authority of Georgia law within Cherokee territory. For an excellent overview of the political history surrounding the Cherokee cases, see Joseph C. Burke, The Cherokee Cases: A Study in Law, Politics, and Morality, 21 Stan L Rev 500 (1969); Francis Paul Prucha, 1 The Great Father 191-213 (Nebraska, 1984); Note, The Cherokee Cases: The Fight to Save the Supreme Court and the Cherokee Indians, 17 Am Ind L Rev 291 (1992). 
dent political entity-a sovereign entity vested with the right of self-determination. ${ }^{14}$ Moreover, the Cherokee Nation's sovereignty was not a product of its treaties with the United States government, but rather a necessary prerequisite to enter into those treaties. ${ }^{15}$ The Supreme Court has implicitly followed the reasoning of Worcester to find that tribal rights of self-government are reflected in, but not created by, federal treaties and statutes. ${ }^{16}$ According to Chief Justice Marshall, tribal sovereignty restricts the full exercise of state authority within state borders because tribal independence preceded the formation of the states themselves. Indian nations possessed the inherent rights of sovereignty because they were "separated from Europe" and "independent of each other and of the rest of the world."17 Thus neither colonization nor the creation of the federal system diminished the Indians' right to be free of interference from state law. ${ }^{18}$

Chief Justice Marshall's sweeping affirmation of tribal rights of self-government against state infringement in Worcester did not diminish federal authority. The Doctrine of Conquest ${ }^{19}$ and the Supremacy Clause ${ }^{20}$ give the federal government ample power to limit the full exercise of tribal sovereignty. The plenary powers of Congress include the power to restrict tribal rights of self-government to maintain external relations; for example, Congress can preclude tribes from entering into treaties or maintaining military forces. ${ }^{21}$ Because the federal government can effectively deny Indian nations their inherent sovereignty, Chief Justice Marshall came to describe Indian tribes as "domestic dependent nations."22

14 Worcester, 31 US at 556-57.

15 Id at 559-61.

16 See, for example, White Mountain Apache Tribe, 448 US at 143.

17 Worcester, 31 US at 542-43.

${ }^{18}$ Id at 559-61.

19 See Johnson $v$ McIntosh, 21 US (8 Wheat) 543, 574 (1823). See also Cohen, Handbook at 93 (cited in note 4) (War powers "underlay much of the federal power exercised over Indian land and Indians during.the early history of the Republic. In international law conquest brings legal power to govern.").

${ }^{20}$ US Const, Art VI, cl 2. See also the Commerce Clause, US Const, Art I, § 8, cl 3 (Congress has power "[t]o regulate commerce ... with the Indian tribes"), and the Treaty Clause, US Const, Art II, $\S 2, \mathrm{cl} 2$, interpreted as granting power to make treaties with Indian tribes in United States $v$ Forty-Three Gallons of Whiskey, 93 US 188 (1876).

${ }^{21}$ See Cohen, Handbook at $274 \mathrm{n} 64$.

22 Cherokee Nation $v$ Georgia, 30 US (5 Pet) 1, 17 (1831). If Congress is to limit the tribal rights of self-government, however, Congress must do so explicitly. In Ex Parte Crow Dog, 109 US 556, 572 (1883), the Supreme Court held that "a clear expression of the 
The Supreme Court returned to the issue of state/tribal jurisdictional conflict in the 1959 case of Williams $v$ Lee. ${ }^{23}$ The Court reaffirmed Worcester's protection of tribal sovereignty, concluding that the tribal rights of self-determination are an essential consideration in state/tribal jurisdictional conflicts. Where Congress has not narrowed the tribal rights of self-government, "the question has always been whether the state action infringed on the right of reservation Indians to make their own laws and be ruled by them." By framing the central issue in terms of "infringement" on the tribal rights of self-government, Williams affirmed Chief Justice Marshall's notion that tribal political independence is a singularly sufficient basis for proscribing the extension of state civil jurisdiction into Indian Country.

In McClanahan $v$ Arizona State Tax Commission, ${ }^{25}$ however, the Court shifted the focus of inquiry in jurisdictional conflict cases from whether a state's action infringed upon the tribal rights of self-government to whether state civil jurisdiction contradicted the federal law governing federal tribal relations.

[T] he trend has been away from the idea of inherent Indian sovereignty as a bar to state jurisdiction and toward reliance on federal pre-emption. The modern cases thus tend to avoid reliance on platonic notions of Indian sovereignty and to look instead to the applicable treaties and statutes which define the limits of state power. ${ }^{26}$

McClanahan left unclear both the usefulness of the Williams infringement test and the continued significance of Chief Justice Marshall's reasoning in Worcester. McClanahan did not explicitly invalidate the Williams infringement test, but by focusing on whether federal law preempted the state action, the opinion reduced the capacity of the tribal rights of self-government to preclude state authority. Tribal sovereignty continued to be a relevant component in the analysis of state/tribal jurisdictional con-

intention of Congress" was required to permit federal territorial court jurisdiction over a criminal case involving only Indian parties. Congress responded by passing the Major Crimes Act, 23 Stat 362, 385 (1885), giving federal courts jurisdiction over certain crimes committed by Indians in Indian Country regardless of the race of the victim. Subsequently, in United States v Kagama, 118 US 375 (1886), the Supreme Court found the Major Crimes Act a valid exercise of Congressional authority, upholding the power of Congress to regulate conduct between Indians in Indian Country.

23358 US 217 (1959).

24 Id at 220 (emphasis added).

25411 US 164 (1973).

26 Id at 172 (citations and footnotes omitted). 
flicts, but it appeared "relegated to a pleasant doctrine slowly vanishing into ambiguity."27

The Supreme Court confronted the confusion generated by Williams and McClanahan in White Mountain Apache Tribe $v$ Bracker. ${ }^{28}$ The Supreme Court held that both tribal rights to self-government and federal preemption of state authority are relevant considerations in the resolution of state/tribal jurisdictional disputes. ${ }^{29}$ Thus, White Mountain Apache recognized the importance of tribal sovereignty in the resolution of state/tribal jurisdictional conflicts and reestablished sovereignty rights as a bar to the extension of state authority into Indian Country. ${ }^{30}$

\section{B. Montana $v$ United States: Guidance for the Infringement Test}

Tribal rights of self-government and inherent tribal sovereignity have remained vague concepts throughout the modern era. Williams did not articulate what tribal interests are to be taken into account when applying the infringement test. But in Montana $v$ United States, while addressing the issue of civil jurisdiction in Indian Country and the inherent rights of a tribe to regulate internal affairs, the Supreme Court outlined the essential elements of the tribal rights of self-government. ${ }^{31}$

A tribe may also retain inherent power to exercise civil authority over the conduct of non-Indians on fee lands within its reservation when that conduct threatens or has some direct effect on the political integrity, the economic security, or the health or welfare of the tribe.

The Montana Court's own application of this "test" narrowed,

27 Vine Deloria, Jr. and Clifford M. Lytle, American Indians, American Justice 205-07 (Texas, 1983).

${ }^{28} 448$ US 136 (1980).

29 Id at 142-43.

3o Id at 142, quoting Williams, 358 US at 220. See also New Mexico $v$ Mescalero Apache Tribe, 462 US 324, 334 \& n 16 (1983) ("inherent tribal sovereignty" may limit state authority).

31450 US 544 (1981).

32 Id at 566.

${ }^{33}$ Professor Pommersheim has correctly stated that Montana does not establish a bright-line test for resolving tribal jurisdictional issues. Rather, Montana only enumerates the critical broad elements of tribal self-government to be considered when applying the Williams infringement test. Pommersheim, 31 Ariz L Rev at 345 (cited in note 5). Nonetheless, this Comment will refer to these elements (political integrity, economic security, and the health or welfare of the tribe) as the Montana "test" because of the helpful elaboration and development they provide for the Williams infringement inquiry. 
rather than broadened, tribal rights of self-government; the Court held that the inherent tribal rights of self-government do not include the power to regulate the conduct of non-Indians on land owned by non-Indians within reservation boundaries. ${ }^{34}$ The Supreme Court tempered its decision, however, by emphasizing that Indian tribes retain the authority to exercise civil jurisdiction over non-Indians on land not allotted and sold to non-Indians, particularly when a non-Indian contracts or conducts commercial transactions with the tribe or tribal members. ${ }^{35}$

Several critics and commentators have argued that a narrow application of Montana ignores a long line of Indian law cases that preserve tribal power unless its exercise would be inconsistent with the interests of the federal government. ${ }^{36}$ In Brendale $v$ Confederated Yakima Indian Nation, Justice Blackmun argued that Montana "must be read against the rich and extensive background of these cases."37 According to Blackmun, Montana "contemplates [ ] the exercise of civil jurisdiction over non-Indian activities... where those... activities implicate a significant tribal interest."38 Indeed, the Montana Court found that the Crow Tribe lacked the authority to regulate non-Indian conduct only because the tribe failed to plead that the conduct at issue, or Montana's regulation thereof, affected any tribal interest. ${ }^{39}$

In order to resist a state's assertion of jurisdiction, therefore, an Indian tribe must assert and substantially prove that state authority threatens or directly implicates a tribal interest in: 1) the political autonomy of tribal institutions, 2) the economic security of the tribe, or 3) the general well-being of its members. An unfortunate corollary of the Montana test is that the requirement of affirmative pleading places a burden on Indian tribes to justify jurisdiction. ${ }^{40}$ In contrast, state courts can generally assume jurisdiction over any matter in which they can assume valid per-

34 Montana, 450 US at 557.

35 Id at 565-66.

${ }^{36}$ See Brendale $v$ Confederated Yakima Nation, 492 US 408, 450 (1989) (Blackmun concurring in part and dissenting in part), citing Washington $v$ Confederated Tribes, 447 US 134, 153 (1980). See also Montana, 450 US at 566 n 16; William C. Canby, The Status of Indian Tribes in American Law Today, 62 Wash L Rev 1, 15-16 (1987); Alvin J. Ziontz, Indian Litigation, in Sandra L. Cadwalader and Vine Deloria, Jr., eds, The Aggressions of Civilization 149, 176-77 (Temple, 1984).

37 Brendale, 492 US at 450 (Blackmun concurring in part and dissenting in part).

38 Id.

${ }^{39}$ Montana, 450 US at $558 \mathrm{n}$ 6, 566 n 16. See also Brendale, 492 US at 459 (Blackmun concurring in part and dissenting in part).

40 See Ziontz, Indian Litigation at 176-77 (cited in note 36). 
sonal and subject matter jurisdiction, regardless of whether the litigation affects the state's general welfare. ${ }^{41}$ Despite its shortcomings, however, Montana provides useful substantive criteria for determining whether state jurisdiction infringes upon tribal authority within Indian Country.

\section{Tribal Rights of Self-Government and the Tribal Courts}

An essential element of tribal self-government is the establishment and development of tribal courts. The Court recognized this in Williams when (after finding that the tribal court could hear the suit and provide a remedy) it refused to extend state jurisdiction, holding that to do so would infringe on the right of self-government by undermining the authority of tribal courts. ${ }^{42}$ Combining this principle with Supreme Court dicta implying that a state may obtain jurisdiction over a matter arising out of Indian Country where a tribe has not established a system of selfgovernment, ${ }^{43}$ state courts have, however, permitted state court civil jurisdiction where tribal courts do not exist. ${ }^{44}$

In National Farmers Union Insurance Cos. $v$ Crow Tribe of Indians, the Supreme Court established procedural safeguards to ensure that federal courts do not infringe upon tribal rights of self-government by usurping the jurisdiction of the tribal courts. ${ }^{45}$ Specifically, federal courts can review tribal court jurisdiction under 28 USC $\S 1331$ only after the parties fully exhaust all available tribal court remedies. ${ }^{46}$ The Court reasoned that the federal policy of encouraging tribal self-government and the development of tribal courts demands that the "forum whose jurisdiction is being challenged [be given] the first opportunity to evaluate the factual and legal bases for the challenges." ${ }^{37}$

41 See generally 21 CJS Courts \$§ 54-64 (1990).

42358 US at 223. See also Note, State Jurisdiction over Indians as a Subject of Federal Common Law: The Infringement-Preemption Test, 21 Ariz L Rev 85, 100 (1979) (discussing the Williams infringement test).

${ }^{43}$ See McClanahan, 411 US at 167-68.

44 See Wildcatt $v$ Smith, 69 NC App 1, 316 SE2d 870, 876 (1984); R.G. $v$ W.M.B., 159 Wis 2d 662, 465 NW2d 221, 224-225 (Wis App 1990) (holding that a state court that had properly acquired jurisdiction prior to the creation of the tribal court continued to exercise valid jurisdiction over the matter-an exception to the general rule that the existence of a tribal court precludes state court jurisdiction).

45471 US 845 (1985).

${ }^{46}$ Id at 856-57; Iowa Mutual Insurance Co. v LaPlante, 480 US 9, 16 (1987) (diversity case; same rule applied).

47 National Farmers Union, 471 US at 856. 
The Supreme Court found that tribal courts are the most appropriate forum to determine jurisdiction in light of the particularized circumstances of tribal sovereignty. ${ }^{48}$ A tribe's rights of self-government may have been diminished or qualified over the years. On the other hand, treaties and federal statutes may ensure specific rights, such as off-reservation hunting and fishing rights. The Supreme Court recognized the advantages of requiring parties to exhaust tribal court remedies: in the event of federal judicial review, federal courts can draw on the Indian court's expertise in such matters. ${ }^{49}$

The Supreme Court has thus consistently held that tribal rights of self-government prevent the extension of state court jurisdiction into Indian Country. The Montana test enumerates several substantive elements of the tribal rights of self-government upon which a state court cannot infringe. Furthermore, the Supreme Court requires that federal courts defer to tribal selfgovernment prerogatives by refusing to hear a case until litigants exhaust tribal court remedies. The exhaustion doctrine preserves the inherent tribal rights of self-determination by presuming tribal court civil jurisdiction over reservation-based suits unless Congress unequivocally legislates to the contrary. ${ }^{50}$

48 Id at 855-56.

49 Id at 857. Here, Congress's grant of general federal question jurisdiction, 28 USC $\S$ 1331 (1988), served as the basis for federal review of tribal court jurisdiction.

so See note 22; Williams, 358 US at 223 ("If this power is to be taken away from them, it is for Congress to do it.").

It is extremely unlikely that Congress will ever divest the tribal courts of this jurisdiction. While Congress has reduced the scope of tribal authority in the past, see Act of August 15, 1953, Pub L No 83-280, 67 Stat 588 (1953), codified at 28 USC $\S 1360$ (1988) (requiring certain states to assume concurrent jurisdiction over civil matters arising out of Indian Country, while providing all other states with the option of assuming civil jurisdiction over Indian Country on their own initiative), Congress amended Public Law 280 in 1968 to require tribal consent for the extension of state jurisdiction and to establish provisions for the retrocession of state jurisdiction. Act of April 11, 1968, Pub L No 90284, 82 Stat 73, 78-81 (1968), codified at 25 USC \$ 1321-23, 1326 (1988). See also Rosebud Sioux Tribe v South Dakota, 900 F2d 1164, 1174 (8th Cir 1990). Moreover, the federal government has encouraged tribal self-government and the development of competent tribal judicial institutions since approximately 1968. See William C. Canby, Jr., American Indian Law in a Nutshell 52-56 (West, 1988) (discussing the history and ultimate abandonment of the federal government's "termination" policy-under which the federal government sought to terminate federal benefits and support services to certain tribes and force the dissolution of reservations). The Indian Self-determination and Education Assistance Act, for example, directed the Department of Health, Education, and Welfare and the Department of the Interior to include provisions in contracts for tribes to ultimately assume responsibility of federal Indian programs. See 25 USC $\$ \S 450-450 \mathrm{n}, 455-$ $458 \mathrm{e}$ (1988). Federal infringement on tribal rights of self-government is extremely unlikely so long as such federal policies and programs are in place, and thus the exclusive jurisdiction of tribal courts over civil cases arising within Indian country and involving 


\section{ENFORCING A STATE COURT ORDER AGAINST AN INDIAN DEBTOR: DOES "NO LAW" MEAN "NO PROBLEM" FOR STATE COURT JURISDICTION?}

Williams $v$ Lee resolves many state/tribal jurisdictional conflicts clearly: where state court jurisdiction infringes upon tribal rights of self-government, plaintiffs must bring suit in the tribal court. ${ }^{51}$ In Williams, a non-Indian store owner who did business within the Navajo Nation brought an action for debt against a Navajo couple. The Supreme Court held that state court jurisdiction over the civil suit would "undermine the authority of the tribal courts over Reservation affairs and hence would infringe on the right of the Indians to govern themselves. ${ }^{.52}$

Williams does not provide guidance in all debt collection cases, however. Suppose that an Indian living and working in Indian Country enters into a contract with a non-Indian outside the boundaries of her reservation and subsequently defaults on her obligations. ${ }^{53}$ The state trial court has subject matter jurisdiction over the underlying litigation because the Indian defendant and the non-Indian plaintiff transacted business outside of Indian Country. ${ }^{54}$ After the trial court enters judgment against the Indian defendant, the non-Indian plaintiff may seek to enforce the judgment by securing a writ of garnishment and serving it on the Indian defendant's employer on the reservation. If the relevant tribal code neither permitted nor prohibited the garnishment of a tribal member's on-reservation wages, would the writ infringe the tribal rights of self-government? Lower federal courts and state courts are divided on this issue. This section analyzes the case law addressing this "no law" problem-primarily those cases involving the garnishment of an Indian's on-reservation wages to enforce a valid state court judgment.

Indian defendants seems secure.

51358 US at 220. Compare Oliphant v Suquamish Indian Tribe, 435 US 191 (1978) (tribal courts may not criminally prosecute non-Indians).

52358 US at 223.

53 Living on a reservation within a state's borders does not constitute sufficient minimum contacts for personal jurisdiction. Nenna $v$ Moreno, 132 Ariz 565, 647 P2d 1163, 1164 (Ariz App 1982); Flammond v Flammond, 190 Mont 350, 621 P2d 471, 473 (1980).

${ }_{54}$ Mescalero Apache Tribe $v$ Jones, 411 US 145, 148-49 (1973); Organized Village of Kake $v$ Egan, 369 US 60, 75 (1962) ("State authority over Indians is [ ] more extensive over activities ... not on any reservation."). 
A. Imagining a World Without Tribes: Narrowly Construing the Tribal Rights of Self-Government

In the absence of a congressional act granting a state civil jurisdiction over Indian Country, the Williams Court asked "whether the state action infringed on the right of reservation Indians to make their own laws and be ruled by them" to determine whether a state could assert such jurisdiction. ${ }^{55}$ When applying the Williams infringement test, Montana and Wisconsin state courts narrowly construe the two components of the tribal rights of self-government-the right to address issues through legislation and the right to be ruled by tribal law. They conclude that state court jurisdiction over the enforcement of a state court order in Indian Country does not infringe upon the tribal rights of self-government. ${ }^{56}$

\section{The right to create tribal law.}

Applying state law that unambiguously contravenes tribal law clearly infringes upon the tribal rights of self-government. ${ }^{57}$ Montana and Wisconsin state courts have applied what they believe to be a corollary of that proposition: if there is no written tribal law addressing the underlying issue, then the tribal court is not exercising its tribal rights of self-government, and state court jurisdiction therefore does not impinge upon the tribal rights of self-government.

In Little Horn State Bank v Stops, the defendants contested the Montana state trial court's jurisdiction to enter a writ of execution authorizing the garnishment of their on-reservation income. ${ }^{58}$ The relevant tribal code did not provide for the attachment of property by non-Indian lenders. ${ }^{59}$ The Montana Supreme Court held that enforcing the state court judgment against

$55358 \mathrm{US}$ at 220.

s6 See, for example, Little Horn State Bank v Stops, 170 Mont 510, 555 P2d 211 (1976); R.G., 465 NW2d 221.

${ }^{57}$ See, for example, Geiger v Pierce, 233 Mont 18, 758 P2d 279, 280-81 (1988).

58170 Mont 510, 555 P2d 211, 212 (1976). The Montana state trial court obtained personal jurisdiction over the Indian defendant through service of process on the Crow reservation. See Dixon v Picopa Construction Co., 160 Ariz 251, 772 P2d 1104, 1113 (1989) (holding that tribal sovereignty demands that service of process be made in accord with tribal law). But see State Securities, Inc. $v$ Anderson, 84 NM 629, 506 P2d 786, 787-88 (1973) (holding that service of process according to state law does not infringe upon tribal sovereignty). See also Robert Laurence, Service of Process and Execution of Judgment on Indian Reservations, 10 Am Ind L Rev 257, 259-268 (1982).

$5955 \mathrm{P} 2 \mathrm{~d}$ at 214. 
the Crow defendants did not interfere with the tribal rights of selfgovernment because the Crow Tribal Code was silent. ${ }^{60}$ Wisconsin state courts similarly equate tribal self-rule with express manifestations of tribal legislative authority, holding that state court jurisdiction infringes upon tribal sovereignty only where a written tribal law addresses the issue in controversy. ${ }^{61}$

The Montana and Wisconsin courts look to the relevant tribal code to determine whether tribal law precludes state court jurisdiction. ${ }^{62}$ In First $v$ LaRoche, the South Dakota Office of Child Support Enforcement sought to enforce a South Dakota judgment against an Indian defendant through URESA ${ }^{63}$ procedures authorizing the Montana Child Support Enforcement Division ("Montana CSED") to act on its behalf. ${ }^{64}$ Montana CSED attempted to intercept the Indian defendant's unemployment insurance benefits to satisfy the South Dakota judgment. The relevant tribal code, the Fort Peck Tribe's Comprehensive Code of Justice, $\S 304(\mathrm{~b})$ and $\S 311$, addressed the execution of the state child support order, arguably providing the plaintiff a remedy. ${ }^{65}$ The First court distinguished the remedies at tribal law and state law to find that the Montana CSED's administrative action did not interfere with tribal legislative authority. Specifically, the court found that the tribal code did not specifically "provide for income withholding proceedings against a tribal member's offreservation income to enforce a child support obligation."66

In a vigorous dissent, Justice Trieweiler challenged the majority's assumption that a tribal code must, at a minimum, provide remedies equivalent to state law remedies to preclude

60 Id.

61 See R.G., 465 NW2d at 224 (finding no tribal code provision addressing paternity and child support and no tribal court to adjudicate the claim at the time the suit was filed); Jacobs $v$ Jacobs, 138 Wis 2d 19, 405 NW2d 668, 672 (Wis App 1987) (tribal code was silent on issue of domestic relations); County of Vilas $v$ Chapman, 122 Wis 2d 211, 361 NW2d 699, 702 (1985) (no motor vehicle provisions in tribal code).

62 See especially Iron Bear v District Court, 162 Mont 335, 512 P2d'1292, 1299 (1973) (adding a third prong to the infringement-preemption test: "whether the Tribal Court is currently exercising jurisdiction in such a manner as to preempt state jurisdiction").

63 The Uniform Reciprocal Enforcement of Support Act (URESA) is a model act requiring all adopting states to enforce foreign support orders against absentee parents within their boundaries. See, generally, Margaret Campbell Haynes and G. Diane Dodson, Interstate Child Support Remedies 63-65 (ABA Center on Children and the Law, 1989). See also Kulko v California Superior Court, 436 US 84, 98-99 (1978).

64247 Mont 465, 808 P2d 467 (1991). Although First rejected the Iron Bear test, it applied the same analytical framework by inquiring into the adequacy of the tribal court remedies. Id at 470-72.

65 Id at 472 .

66 Id. 
state court jurisdiction. Justice Trieweiler argued that Montana could effectively "substitute its system of [laws] for the tribal system" by merely finding the tribal code deficient in light of the specific case. ${ }^{67}$ The lower court had similarly noted that, on the plaintiff's reasoning, if a state government creates a mechanism for adoption that differs only slightly from the tribal adoption law, the state courts could assert jurisdiction over the proceedings without infringing upon tribal legislative authority. ${ }^{68}$

Justice Trieweiler's concerns are borne out by Wisconsin Supreme Court precedent, which determines whether tribal law precludes state authority by asking whether the tribal code is sufficiently similar to state law. For example, the Wisconsin Supreme Court assessed the sufficiency of traffic regulations in the Menominee Law and Order Code by asking whether they substantially mirrored Wisconsin traffic regulations. ${ }^{69}$ Thus, in Wisconsin and Montana, state law is the benchmark by which courts determine whether a tribe is sufficiently exercising its selfgovernment rights so as to preclude state court jurisdiction.

2. The right to be ruled by tribal law.

The second element of the tribal rights of self-government-the right to be ruled by tribal law ${ }^{70}$-poses difficult conceptual problems for courts and commentators. The determination of whether state jurisdiction infringes upon political liberty is treacherous, as courts are unsure of how much deference to afford tribal courts. Accordingly, some state courts struggle to fit Indian tribes into a strict federal framework, resolving the state/tribal court jurisdictional conflict by resorting to the familiar federal system: a system uncomplicated by Indian tribes, and, not surprisingly, unprotective of tribal interests.

Since the federal system requires states to defer only to other states or to the federal government, only comity would preclude the extension of state court jurisdiction into Indian Country. Under the principle of comity, a court will give effect to the laws and holdings of another forum not as a matter of obligation,

67 Id at 475 (Trieweiler dissenting).

${ }_{68}$ See First $v$ LaRoche, 17 Ind L Rptr 5002, 5003 (Mont 1st Jud Dist 1989).

${ }^{69}$ See, for example, State $v$ Webster, 114 Wis 2d 418, 338 NW2d 474, 482 (1983) (finding tribal regulations substantially similar to state regulations and therefore sufficient to preclude state jurisdiction). See also County of Vilas, 361 NW2d at 702 (finding that state regulation of traffic on an Indian reservation did not interfere with tribal sovereignty where the tribe had no traffic code).

70 See Williams, 358 US at 220. 
but out of deference and mutual respect. ${ }^{71}$ Little Horn State Bank adopted a narrow view of the right of Indians to be ruled by their own laws, reasoning that it would have to recognize Indian tribes as "sister states" to defer to the authority of the Crow Tribe over its members and property within the reservation boundaries. ${ }^{72}$ The court concluded that respecting the tribe's right to refuse enforcement of the judgment would be anomalous because the Full Faith and Credit Clause does not apply to Indian tribes. ${ }^{73}$ Moreover, the Little Horn State Bank court stressed that the "essential elements of a valid writ of execution existed" and that Montana state court jurisdiction over the enforcement of the judgment debt would be incontrovertible but for the Crow Reservation. ${ }^{74}$

State and federal courts are rightfully concerned with obligations imposed by state law and federal law; accordingly, Little Horn State Bank evidences the Montana court's interest in providing the plaintiff a remedy. The Montana Supreme Court has consistently held that Montana state law was the only source for an adequate remedy to a plaintiff, and that the court had to assume jurisdiction to ensure that the plaintiff's rights guaranteed by state law were not disregarded. ${ }^{75}$ In the view of the Montana court, the tribal code's silence on the issue implicitly validates and justifies the extension of state authority into tribal land.

B. A World Where Tribes Are States: The Navajo Debt Collection Cases

Arizona state courts and some federal courts interpret tribal rights of self-government more broadly, analogizing the tribal rights of self-government to the sovereign powers of a state in

71 Brown v Babbitt Ford, Inc., 117 Ariz 192, 571 P2d 689, 695 (Ariz App 1977). See also Hilton $v$ Guyot, 159 US 113, 163-64 (1895).

72555 P2d at 212.

73 Id (treating the tribe on an "even par" with the states "would not be feasible, since the Crow Tribe does not provide for the honoring of state court judgments, nor is the fullfaith [sic] and credit clause applicable to the tribe"). For a discussion of full faith and credit and Indian tribes, see William V. Vetter, Of Tribal Courts and "Territories": Is Full Faith and Credit Required?, $23 \mathrm{Cal} \mathrm{W} \mathrm{L} \mathrm{Rev} \mathrm{219,} \mathrm{269-72} \mathrm{(1987)} \mathrm{(arguing} \mathrm{that} \mathrm{tribal} \mathrm{court}$ judgments should be recognized under principles of comity); Comment, Recognition of Tribal Decisions in State Courts, 37 Stan L Rev 1397, 1412-17 (1985); Robert N. Clinton, Tribal Courts and the Federal Union, 1989 Harv Ind L Symp 17, 70-75 (arguing that tribal court judgments should be given full faith and credit).

74555 P2d at 212.

75 Id at 215. 
cases involving the enforcement of state court judgments within the Navajo Nation. ${ }^{76}$ Although the Navajo Tribal Code provides several methods of enforcing judgments, it does not provide for garnishment of on-reservation wages. The Navajo Tribal Code allows a Navajo District Court to enter judgments ${ }^{77}$ as well as writs of execution. ${ }^{78}$ The Navajo court may attach livestock and other property, but the Navajo Tribal Council repealed the tribal law providing for the garnishment of wages within Navajo territory. ${ }^{79}$

A federal district court may not execute a writ of garnishment where a state or territory does not provide for the attachment of wages. Garnishment is a statutory remedy which did not exist at common law and does not exist now in all jurisdictions. ${ }^{80}$ In First National Bank of Boston $v$ Santisteban, the First Circuit Court of Appeals upheld the district court's refusal to attach future wages because Puerto Rican law did not provide for garnishment of future wages as a means to satisfy judgments. ${ }^{81}$ In an action for execution of a judgment at the federal level, Rule 69(a) of the Federal Rules of Civil Procedure respects the authority of state governments and directs federal district courts to look to state law for possible remedies. ${ }^{82}$ Rule 69 (a) is merely procedural and cannot enlarge or abridge substantive rights defined by state law. ${ }^{83}$ Where there is no controlling federal statutory law, the district court has the same authority to enforce judgments as that provided to state courts under local law. ${ }^{84}$

${ }^{76}$ See Joe v Marcum, 621 F2d 358, 361-62 (10th Cir 1980); United States v Morris, 754 F Supp 185, 187-88 (D NM 1991); Begay v Roberts, 167 Ariz 375, 807 P2d 1111, 111417 (Ariz App 1990).

777 Nav TC \& 701 (Supp 1984-85).

787 Nav TC \& 705 (Supp 1984-85).

${ }^{79} 9$ Nav TC $\& 1303$ (1978) (authorizing garnishment of wages for the enforcement of child support orders), repealed by 9 Nav TC $\$ 711$ (Supp 1984-85).

${ }^{80}$ Joe, $621 \mathrm{~F} 2 \mathrm{~d}$ at 361.

8I 285 F2d 855 (1st Cir 1961). The district court cited this decision in Morris, 754 F Supp at 186.

*2 Such proceedings "shall be in accordance with the practice and procedure of the state in which the district court is held, existing at the time the remedy is sought...." FRCP 69(a).

${ }^{83}$ See 28 USC $\S 2072(b)$ (1988); Argento $v$ Village of Melrose Park, 838 F2d 1483, 1487 (7th Cir 1988) ("the federal rules neither create nor withdraw jurisdiction"); Kashi $v$ Gratsos, 712 F Supp 23, 25 (S D NY 1989).

\& Goldman v Meredith, 596 F2d 1353, 1357 (8th Cir 1979). See also Marshak v Green, 746 F2d 927, 931 (2d Cir 1984); Duchek v Jacobi, 646 F2d 415, 417 (9th Cir 1981); Crosson $v$ Conlee, 745 F2d 896, 903-04 (4th Cir 1984). 
Case law involving Rule 69(a) and debt collection reflects the conflict-of-laws principle that a court must respect another jurisdiction's affirmative choice not to provide a certain remedy. In Northwest South Dakota Production Credit Association $v$ Smith ("PCA"), the Eighth Circuit reasoned that a federal court must similarly defer to tribal preferences regarding remedies and enforcement mechanisms in a suit brought by off-reservation creditors for a debt owed by Indians on a reservation. ${ }^{85} \mathrm{~A}$ federal statute authorizing the mortgage and alienation of reservation trust land provided that such mortgages and foreclosures were to be made "in accordance with the laws of the State or Territory in which the land is located." tory language and legislative history of 25 USC $\S 483($ a) that there was no federal court jurisdiction over the mortgaging or foreclosure of Indian trust land.

The PCA court rejected the creditor's argument that the federal court was the only forum in which it could obtain relief because the creditor had "not presented its claim to the Cheyenne River Sioux Tribal Court." ${ }^{\prime 87}$ The court stated that the tribal court "appears ... to be the proper forum" and that it should decide whether it had jurisdiction over the action. ${ }^{88}$ While the PCA court applied the doctrine of exhaustion which had been established only a year before in National Farmers Union, ${ }^{89}$ other courts had recognized tribal courts as the appropriate forums prior to National Farmers Union..$^{90}$

In sum, a court's view of the "no law" problem depends on the court's conception of the tribal rights of self-government. The

85 784 F2d 323 (8th Cir 1986). Similarly, in Joe, 621 F2d at 361-62, the Tenth Circuit analogized Indian tribal governments to state governments and held that the state could not exercise a writ of garnishment in Indian Country without tribal authorization. See also Morris, $754 \mathrm{~F}$ Supp at 187. Courts have afforded tribes status equal to states with respect to specific statutes. See Tracy $v$ Superior Court, 168 Ariz 21, 810 P2d 1030, 103846 (1991); Martinez v Superior Court, 152 Ariz 300, 731 P2d 1244, 1247-48 (Ariz App 1987).

$86784 \mathrm{~F} 2 \mathrm{~d}$ at 324 , quoting 25 USC § 483(a) (1988).

87 Id at 327.

${ }^{88}$ Id. See also Santisteban, 285 F2d at 856. In that case, the bank argued that its only remedy would be a federal court order obliging the debtor to pay or be held in contempt of court. The appellate court stated tersely that "the United States District Court is not a collection agency" and it could not endorse a remedy not provided by Puerto Rican law. Id.

89 471 US 845,857 (1985).

90 See, for example, American Indian National Bank v Red Owl, 478 F Supp 302, 305 (D SD 1979); Flammond v Flammond, 190 Mont 350, 621 P2d 471, 474 (1980). Compare Schantz $v$ White Lighting, 502 F2d 67, 69-70 (8th Cir 1974) (denying federal jurisdiction where the tribal code expressly refused jurisdiction over the controversy). 
Montana-Wisconsin line of cases interprets the tribal rights of self-government narrowly, demanding a clear showing that state court jurisdiction would contradict an unequivocal expression of tribal governmental authority. The Navajo Debt Collection cases analogize tribal governmental authority to state sovereignty, holding that tribes have the prerogative not to provide a remedy provided by state law.

\section{OUTLINING THE SCOPE OF TRIBAL RIGHTS OF SELF- GOVERNMENT}

In Iowa Mutual Insurance Co. $v$ LaPlante, the Supreme Court stated in dicta that the tribal rights of self-determination could prevent the extension of state court jurisdiction where the relevant tribal code is silent. ${ }^{91}$ Specifically, when federal law has not clearly narrowed tribal rights of self-determination, "the proper inference from [tribal] silence ... is that the sovereign power .. . remains intact." ${ }^{.92}$ Like Williams, Iowa Mutual explicitly recognized that tribal rights of self-government may sometimes trump state (and federal) interests. However, the Supreme Court did not elaborate precisely which "sovereign power[s] remain [ ] intact." Bes Because the Court has failed to define clearly the tribal rights of self-government, the two lines of cases addressing the enforcement of state court orders in Indian Country have misconstrued those rights.

\section{A. Analysis of the "No Law" Cases}

The Navajo Debt Collection cases improperly characterize the tribal right of self-government; the Supreme Court has clearly stated that Indian tribes are not states. ${ }^{94}$ The tribal rights of self-government are different from the sovereign rights of a state. For example, Indian tribes are not subject to constitutional limitations on state action. ${ }^{95}$ The Bill of Rights does not apply to Indian tribes. ${ }^{96}$ On the other hand, the federal government can

91480 US 9,18 (1987).

92 Id, quoting Merrion v Jicarilla Apache Tribe, 455 US 130, 148-49 n 14 (1982).

93 See Comment, The Indian Battle for Self-Determination, 58 Cal L Rev 445, 473 (1970) (analyzing Williams).

94 See, for example, White Mountain Apache Tribe v Bracker, 448 US 136, 143 (1980); United States v Kagama, 118 US 375, 379 (1886).

9s Talton $v$ Mayes, 163 US 376, 385 (1896).

96 However, the Indian Civil Rights Act of 1968, 25 USC § 1302 (1988), places similar restraints on tribal governmental actions. 
define and limit the extent to which an Indian tribe may exercise its sovereignty. ${ }^{97}$ The Court has stated that the federal government assumes a trust relationship when dealing with "these dependent and sometimes exploited people" and must fulfill "moral obligations of the highest responsibility and trust."98

The ancient origins and extra-constitutional status of Indian tribes demand different relations and obligations between the federal government and Indian tribes than between the federal government and states. In the seminal Cherokee cases, Chief Justice Marshall looked to international law principles set forth by the French political theoretician Emmerich de Vattel and concluded that Indian nations were political bodies vested with the rights of self-government. ${ }^{99}$ De Vattel defined a sovereign state as a nation that "governs itself . . . without any dependence on a foreign power." 100 Thus, despite the loss of some "national" powers, Indian tribes retain the inherent tribal rights of selfdetermination ${ }^{101}$ by maintaining a status distinct from both state and federal government. ${ }^{102}$

Just as courts that treat Indian tribes as states ignore clear Supreme Court holdings rejecting such a view, courts that supplement tribal code remedies with state law remedies ignore the Supreme Court's consistent holdings against the application of state law in Indian Country. ${ }^{103}$ The Supreme Court has recognized that "[t]he policy of leaving Indians free from state jurisdiction and control is deeply rooted in the Nation's history." ${ }^{104}$ The Montana-Wisconsin line of cases fails to respect the fact that the inherent tribal rights of self-government displace state law, even within the state's boundaries.

The inherent tribal rights of self-determination vest tribal courts with jurisdiction over reservation-based civil suits even where tribal courts have not yet exercised that jurisdiction. ${ }^{105} \mathrm{~A}$

97 See Kagama, 118 US at 383-84. See also notes 22 and 49.

93 Seminole Nation v United States, 316 US 286, 296-97 (1942).

${ }_{99}$ See Worcester $v$ Georgia, 31 US (6 Pet) 515, 560-61 (1832).

${ }^{100}$ Emmerich de Vattel, The Law of Nations 16 (Dublin, 1792).

101 See Cohen, Handbook at 122-23, 273-74 (cited in note 4); Canby, 62 Wash L Rev at 1-2 (cited in note 36). See also United States $v$ Wheeler, 435 US 313, 328 (1978).

${ }^{102}$ For example, the Iroquois National Lacrosse team traveled to the 1990 World Lacrosse Championships in Australia on passports issued by the Iroquois Grand Council of Chiefs. United Press International Wire, Iroquois Participation Takes Lacrosse Championships Back to Roots (June 24, 1990).

${ }_{103}$ See Iowa Mutual, 480 US at 18.

104 Rice $v$ Olson, 324 US 786, 789 (1945).

105 See, for example, Fisher $v$ District Court, 424 US 382, 390 (1976) (per curiam). 
tribe may not have addressed the subject of the litigation, but "sovereign power, even when unexercised, ... will remain intact unless surrendered in unmistakable terms." ${ }^{106}$ Furthermore, the exhaustion doctrine, by requiring that tribal courts make the initial jurisdictional decision, implies that the absence of a written tribal law is not dispositive as to whether the tribe retains the authority to address the issue in controversy. ${ }^{107}$

A recognizing forum can execute a judgment where recognition would be "compatible with the maintenance of comity among courts." ${ }^{108}$ In the spirit of mutual respect, and as mandated by URESA, the First court showed great deference to the South Dakota child support order. However, the court disregarded Supreme Court precedent recognizing the primacy of tribal courts. Under Iowa Mutual and National Farmers Union, respect for tribal courts demands that an initial jurisdictional inquiry be made in the tribal courts. Federal courts direct plaintiffs to exhaust their tribal court remedies in recognition of the fact that tribal courts are responsible for enforcing tribal law within Indian Country.

Finally, applying state law in "no law" cases undermines tribal legislative authority because it effectively requires a tribe to legislate in a contextually specific manner that is not only unreasonable but also impossible. ${ }^{109}$ Justice Trieweiler's dissent in First was correct: if applying state law does not infringe upon the tribal rights of self-government where the tribal code does not specifically address a certain situation, a state court can extend state authority into Indian Country without violating the Williams infringement test. ${ }^{110}$ Yet Montana and Wisconsin precedent permits courts to ignore the inherent rights of self-determination and coerce tribal governments to adopt state law in their tribal codes.

${ }^{106}$ Merrion v Jicarilla Apache Tribe, 455 US 130, 148 (1982).

107 See National Farmers Union, 471 US at 856-57.

108 Restatement (Second) of Judgments $\& 82(2)$ (1982).

109 That a statute cannot anticipate all of its applications is reflected by the acceptance of the proposition that judges do not merely judge, but must also legislate. See, for example, Southern Pacific Co. $v$ Jensen, 244 US 205, 221 (1917) (Holmes dissenting) ("[J]udges do and must legislate, but they can do so only interstitially; they are confined from molar to molecular motions.").

${ }^{110}$ See Margery H. Brown and Brenda C. Desmond, Montana Tribal Courts: Influencing the Development of Contemporary Indian Law, 52 Mont L Rev 211, 282 (1991). 
B. Applying the Montana Test to the Enforcement of State Court Judgments in Indian Country

Under the Montana "test" for state/tribal jurisdictional conflicts, state court civil jurisdiction infringes on the tribal rights of self-government where it has an "effect on the political integrity, the economic security, or the health or welfare of the tribe."111 Permitting the assertion of state civil jurisdiction in the "no law" scenario is objectionable because it undermines the "political integrity" of tribal councils and tribal courts. Tribal courts have experienced dramatic development during the period of self-determination and can provide effective forums for enforcing judgments. ${ }^{112}$ As a result of the deliberate effort to develop tribal courts and increase the sophistication of tribal governments, ${ }^{113}$ tribal courts and tribal law now embody the tribal rights of selfgovernment. Thus, a state court that refuses to acknowledge the jurisdictional prerogative of tribal courts or the authority of tribal law wrongly disregards the tribal rights of self-government.

Commentators have often ignored tribal rights of self-government, emphasizing instead that federal law or policy preempts the extension of state court jurisdiction into Indian Country. ${ }^{114}$ In McClanahan v Arizona State Tax Commission, the Supreme Court stated that "the trend has been away from the idea of inherent Indian sovereignty as a bar to state jurisdiction and toward reliance on federal pre-emption."115 Although the Court's emphasis on federal preemption properly limited the extension of state jurisdiction into Indian Country, now is the appropriate time for a more comprehensive definition of the "tribal rights of self-government" that respects tribal political and legal institutions as vested with rights of self-determination.

Tribal courts are the appropriate forums for the enforcement of state court orders-even in a "no law" situation. Accordingly, state courts should direct plaintiffs to seek relief in the relevant

11 Montana, 450 US at 566. See also text accompanying notes 32-33.

112 Montana courts had recognized this fact several years before in Flammond, 621 P2d at 474. The Montana Supreme Court has since reverted to its former distrust and misunderstanding of tribal courts and their role in cases like First $v$ State, 247 Mont 465, 808 P2d 467, 471 (1991).

${ }_{113}$ In 1990, there were approximately 150 tribal courts in the United States, and the number is increasing. H. Ted Rubin, Tribal Courts and State Courts: Disputed Civil Jurisdiction Concerns and Steps Toward Resolution, 14 State Ct J 9, 9 (Spring 1990).

${ }^{114}$ See Earl Mettler, A Unified Theory of Indian Tribal Sovereignty, 30 Hastings I J 89, 112-20 (1978); Note, 21 Ariz L Rev at 88-89 (cited in note 42).

115411 US at 172. 
tribal court. Tribal court jurisdiction preserves tribal political integrity consistent with the holding in Montana $v$ United States.

1. Political integrity and tribal councils.

Felix Cohen described self-government as "that form of government in which decisions are made ... by the people who are most directly affected by the decisions." ${ }^{\text {"16 }}$ The Indians who are affected by tribal council decisions elect tribal council representatives. Tribal councils in turn attempt to determine which laws are most appropriate to circumstances within Indian Country and legislate accordingly.

The council's authority to provide or deny certain remedies to a creditor in a suit against an individual under the tribe's authority is a necessary aspect of tribal self-government. For example, in Babbitt Ford, Inc. $v$ Navajo Indian Tribe, the Ninth Circuit Court of Appeals held that an off-reservation plaintiff could not repossess an Indian defendant's automobile where Navajo tribal law required the defendant's consent to do so. ${ }^{117}$ The Navajo Tribal Council invalidated unilateral repossession of automobiles because it endangered "the health and safety of tribal members" by leaving them stranded "miles from [their] nearest neighbor." 118

If the tribal rights of self-government are to be more than hollow rhetoric, tribal legislative authority must include the prerogative not to address an issue through legislative action. A tribal council undoubtedly exercises tribal rights of self-government by affirmatively enacting a tribal law. Deciding not to legislate on an issue is also an exercise of the rights of self-government. If a state court could extend its laws into Indian Country by providing a remedy by default, then state courts can deny tribal councils the prerogative of not legislating on a particular issue.

\section{Political integrity and tribal custom.}

The right not to legislate on issues is particularly important in Indian Country. For centuries, Indians have resolved internal disputes through unwritten customs and traditions. ${ }^{119}$ The pref-

116 Felix S. Cohen, Indian Self-Government, in Alvin M. Josephy, Jr., ed, Red Power: The American Indians' Fight for Freedom 17-18 (Nebraska, 1971).

117710 F2d 587 (9th Cir 1983).

118 Id at 593.

119 See, for example, Karl N. Llewellyn and E. Adamson Hoebel, The Cheyenne Way 
ace to the Navajo Tribal Code emphasizes this point, warning that "[o]ne should not expect to find all Navajo Tribal laws to be contained within these volumes." ${ }^{120}$ Considering written tribal codes to be the sole source of tribal law is unrealistic because tribal custom may trump written tribal law as well as state law. For example, in In re the Marriage of Napyer, the Yakima National Tribal Court recognized a traditional wedding ceremony (a "Yakima wedding trade") that was contrary to the 1953 Law and Order Code of the Yakima Indian Nation. ${ }^{121}$ The Tribal Court refused to apply the Tribal Code provisions for marriages and marriage dissolution because they conflicted with the Washat religion and therefore were irreconcilable with federal and tribal law protecting tribal custom and traditions. ${ }^{122}$

Courts should be careful to consider the tribal interest in preserving tribal tradition and custom-essential elements of the legacy of tribal self-government-when analyzing the "no law" problem. ${ }^{123}$ The federal government has recognized the importance of tribal custom and has enacted laws to ensure that Native American culture and tradition will be preserved. By not incorporating certain clauses of the Bill of Rights into the Indian Civil Rights Act, and by modifying others, Congress recognized the tribal interest in maintaining custom and tradition. ${ }^{124}$ The Supreme Court has also manifested its respect for the tribal interest in being ruled by tribal tradition and local law. ${ }^{125} \mathrm{By}$ directing plaintiffs to exhaust all their remedies at tribal courts, the exhaustion doctrine ensures that tribal customs and tradition will be taken into account in the resolution of the dispute.

Although tribal custom and tradition are integral elements of tribal self-government, lower courts often relegate tribal court jurisdiction to matters traditionally resolved by tribes or preserved in treaties entered into over one hundred years ago. The "formal-

(Oklahoma, 1941).

120 Nav TC at ix (1977).

12119 Ind L Rptr 6078 (Yak Tr Ct 1992).

122 Id at 6079 . The Tribal Code was adopted in 1952 with guidance from the Bureau of Indian Affairs.

${ }^{123}$ United States $v$ Wheeler, 435 US at 331; Chino v Chino, 90 NM 204, 561 P2d 476, 479 (1977).

${ }_{124} 25$ USC $\S \S 1301-03$ (1988). See Janis $v$ Wilson, 385 F Supp 1143, 1150 (D SD 1974), remanded on other grounds, 521 F2d 724, 729 (8th Cir 1975). See also McCurdy $v$ Steele, 353 F Supp 629, 632-33 (D Utah 1973), reversed on other grounds, 506 F2d 653 (10th Cir 1975).

${ }^{125}$ See Carney $v$ Chapman, 247 US 102 (1918) (holding a customary tribal marriage is legally valid); Ex Parte Crow Dog, 109 US 556, 571 (1883). 
ized in treaty" standard is unreasonable in most situations considering that the federal government stopped making treaties with Indian tribes in $1871^{126}$ and could not have contemplated the modern dilemmas tribes currently confront. For example, in First, the court denied the Fort Peck Tribe the exclusive right to collect child support through income withholding because the Fort Peck Treaty did not guarantee it such a right. ${ }^{127}$ The federal government did not endorse income withholding until 1984, so it is not surprising that it did not address the matter in Indian treaties over one hundred years earlier. ${ }^{128}$

3. Political integrity, tribal courts, and Anglo-American notions of efficient government.

Even where the issue in controversy does not seem to be governed by tribal custom or tradition, assuming that tribal courts cannot respond to the issue undermines the authority of tribal courts. Non-Indian courts project western values of the proper role of legislatures and courts when denying tribal courts the chance to hear a matter of first impression. Tribal courts can be very pragmatic and resolve civil disputes by following procedures and applying substantive law different from state court procedure and substance. For example, in Descheenie v Mariano, the Navajo Supreme Court established a formula for determining child support in the absence of a Tribal Code provision. ${ }^{129}$

We realize that we are treading on legislative ground by setting up these guidelines. However, in the absence of tribal council action, we must do our best to fairly resolve the disputes that come before us, and establish a uniform pattern for resolving those disputes. This is not the first time we have set guidelines when the tribal council has failed to legislate. ${ }^{130}$

Furthermore, tribal courts have a unique institutional capability to resolve disputes in light of different cultural, social, and political norms. Tribal courts are able to "bridge the gap between

${ }^{125}$ Cohen, Handbook at 66-67 (cited in note 4). The federal government continues, however, to enter into "agreements" with Indian tribes. Id at 67.

127808 P2d at 471. See also Application of Otter Tail Power, 451 NW2d 95, 102 (ND 1990) (holding that an 1867 treaty did not guarantee the tribe the right to regulate utilities).

${ }_{123}$ See Wehunt $v$ Ledbetter, 875 F2d 1558, 1569-70 (11th Cir 1989) (Clark dissenting).

12215 Ind L Rptr 6039, 6039-40 (Nav Sup Ct 1988).

130 Id at 6039 (citations omitted). 
law and Indian culture."131 Thus, the Navajo Supreme Court in Descheenie analyzed standard legal principles ("the best interests of the child"), tribal custom ("Navajo custom obligates each Navajo parent to provide for the support of his or her child"), and the current political and economic circumstances of the tribe ("the vast spectrum of social and economic groups existing within the Navajo Nation") to calculate an absentee father's child support obligation. ${ }^{132}$

The exhaustion doctrine embraces the notion that the tribal rights of self-government necessarily encompass the right of tribes to address new circumstances as they develop through the law. ${ }^{133}$ This is consistent with the Supreme Court's analysis of state/tribal jurisdiction, which has "never turned on whether the particular area being regulated is one traditionally within the tribe's control."134 Although some treaties provided for continued self-government over internal affairs, ${ }^{135}$ state jurisdiction is precluded absent an Act of Congress and the consent of the tribe. Thus, the exhaustion doctrine ensures that the tribal right of self-government will not be reduced to "a set of rights minutely fixed in the concrete of history." 136

State courts should respect tribal legislative and judicial authority regardless of tribal code silence on the issue by directing a creditor to tribal court to enforce her judgment. Although it may appear unfair to direct a creditor to secure relief in a jurisdiction whose law does not explicitly provide the same remedies as state law, the desire for identical remedies does not justify infringements on the tribal rights of self-government. In other words, ignoring tribal prerogatives implicates concerns greater

${ }^{131}$ Orville N. Olney and David H. Getches, Indian Courts and the Future: Report of the National American Indian Court Judges Association 93 (National American Indian Court Judges Association, 1978).

13215 Ind L Rptr at 6039-40.

${ }_{133}$ See Santa Clara Pueblo v Martinez, 436 US 49 (1978); Judith Resnik, Dependent Sovereigns: Indian Tribes, States, and the Federal Courts, 56 U Chi L Rev 671, 709 (1989).

${ }^{134}$ Rice $v$ Rehner, 463 US 713, 739 (1983) (Blackmun dissenting), citing Ramah Navajo School Board v Bureau of Revenue of New Mexico, 458 US 832 (1982) (state cannot tax Indian school board); Moe v Salish \& Kootenai Tribes, 425 US 463 (1976) (cigarette tax); Mescalero Apache Tribe $v$ Jones, 411 US 145 (1973) (ski resorts on reservation; state tax upheld in part). Although the language of Rice includes "traditional authority" analysis, 463 US at 722, the decision is arguably based primarily on a congressional grant of authority to states. See id at $723,726$.

${ }^{135}$ See Vine Deloria, Jr. and Clifford M. Lytle, The Nations Within: The Past and Future of American Indian Sovereignty 4 (Pantheon, 1984).

${ }^{136}$ Perry Dane, The Maps of Sovereignty: A Meditation, 12 Cardozo L Rev 959, 968 (1991). 
than creditors' rights. State court jurisdiction in the "no law" scenario contravenes the federal policy of encouraging tribal selfgovernment. Moreover, the application of state creditor-debtor law undermines tribal efforts to create an environment conducive to economic development consistent with tribal needs and expectations. Federal policy and tribal interests in economic self-determination demand that state courts direct a non-Indian creditor to the appropriate tribal court regardless of whether the tribal code explicitly provides the same remedy as state law.

As a practical matter, the creditor is likely to be afforded some relief in tribal court. Some tribal courts provide a creditor with a state or federal law remedy through their choice-of-law provisions. In the "no law" situation, the Navajo Tribal Code directs tribal courts to seek the applicable law in the customs and usages of the Nation, then in federal laws and regulations, and finally, in the laws of the state "in which the matter in dispute may lie."137 The Navajo Nation did not pursue economic activity prior to 1923 , so there is no substantive common law regarding tribal debts or obligations. However, evidence suggests that tradition and custom played, and perhaps continue to play, a large role in the issuing and repayment of personal debt. ${ }^{138}$ If there is no Navajo customary law regarding personal debt obligations, then the Navajo District Court may afford the debtor the same kinds of relief as granted under Arizona, New Mexico, or Utah state law.

In sum, the Supreme Court has stated that state court jurisdiction is invalid where it infringes upon the tribal rights of selfgovernment. Accordingly, state court jurisdiction over the enforcement of state court orders in Indian Country should be invalid because it infringes upon the tribal rights of self-government. Enforcing state court judgments where there is no remedy at tribal law threatens the political integrity of tribal governments and undermines the authority of tribal courts. At the same time, however, respecting the tribal rights of self-government and preserving creditors' rights need not be mutually exclusive endeavors. A state court can accomplish both objectives by directing

1377 Nav TC $\S 204$ (Supp 1984-85).

${ }^{138}$ See Paul E. Frye, Lender Recourse in Indian Country: A Navajo Case Study, 21 NM L Rev 275, 289-91 (1991). But see Michael D. Lieder, Navajo Dispute Resolution and Promissory Obligations: Continuity and Change in the Largest Native American Nation, 18 Am Ind L Rev 1, 17-23, 55-60 (1993) (arguing that virtually all of Navajo contract law is rooted in Anglo-American legal principles). 
the non-Indian plaintiff to seek enforcement in the appropriate tribal court.

\section{CONCLUSION}

In light of Supreme Court precedent and the important role tribal courts play in the exercise of tribal self-rule, state court judgments should be enforced through tribal court proceedings to ensure that the political liberty of Indian tribes is not threatened. To the extent that state civil jurisdiction denies tribal courts the opportunity to apply unwritten law and custom, state civil jurisdiction undermines an integral element of tribal court authority. Tribal rights of self-government and the enforcement of state court judgments are complementary in achieving the mutually shared interests in justice-not only in the immediate litigation, but also in the greater context of federal Indian policy. By fairly considering the tribal interests in the political autonomy of tribal institutions, the economic security of the tribe, and the general well-being of tribal members when determining whether state civil jurisdiction infringes upon the tribal rights of self-government, courts can ensure that ours will not be a world without Indian tribes. 